\title{
DISTRIBUTION OF SOLUBLE AND PRECIPITATED IRON AND CHROMIUM PRODUCTS GENERATED BY ANODIC DISSOLUTION OF 316L STAINLESS STEEL AND ALLOY C-22: FINAL REPORT
}

\author{
Joe Farmer, \\ Dave Silberman \\ John Estill \\ Ken King \\ Steve Gordon \\ Larry Logotetta
}

August 1999

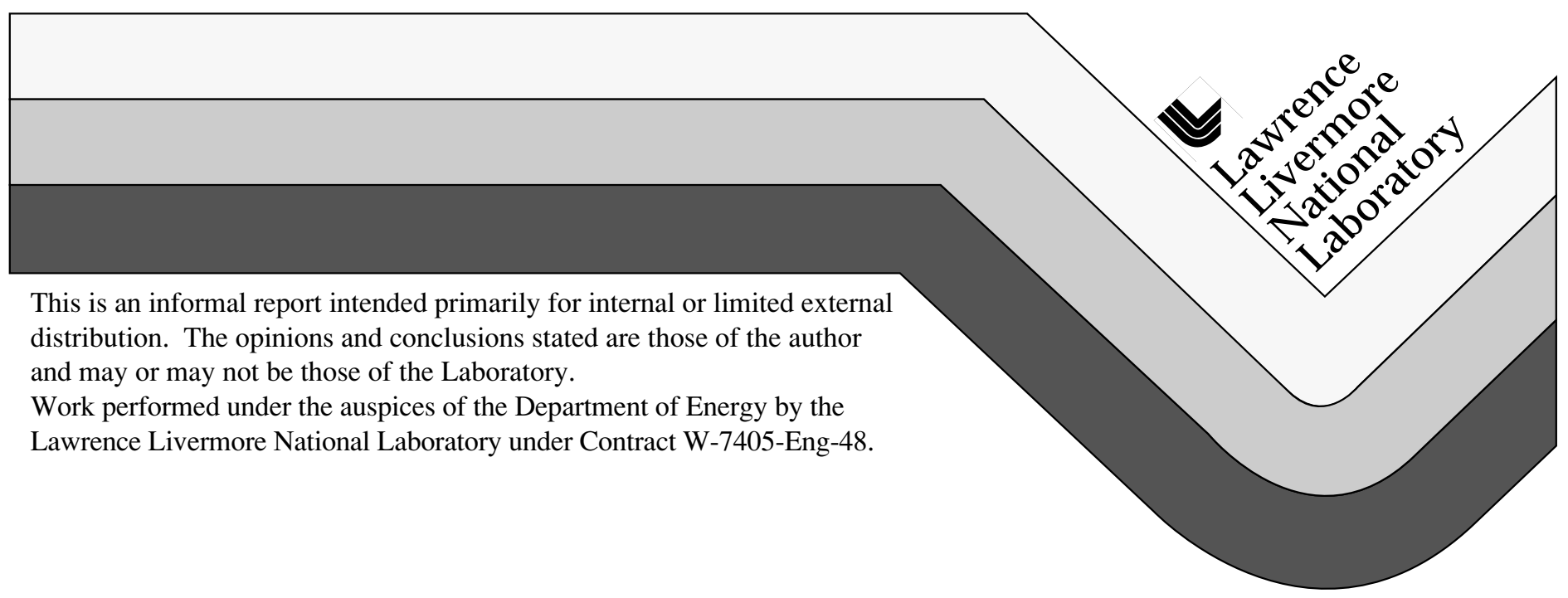




\section{DISCLAIMER}

This document was prepared as an account of work sponsored by an agency of the United States Government. Neither the United States Government nor the University of California nor any of their employees, makes any warranty, express or implied, or assumes any legal liability or responsibility for the accuracy, completeness, or usefulness of any information, apparatus, product, or process disclosed, or represents that its use would not infringe privately owned rights.

Reference herein to any specific commercial product, process, or service by trade name, trademark, manufacturer, or otherwise, does not necessarily constitute or imply its endorsement, recommendation, or favoring by the United States Government or the University of California. The views and opinions of authors expressed herein do not necessarily state or reflect those of the United States Government or the University of California, and shall not be used for advertising or product endorsement purposes.

This report has been reproduced

directly from the best available copy.

Available to DOE and DOE contractors from the

Office of Scientific and Technical Information

P.O. Box 62, Oak Ridge, TN 37831

Prices available from (615) 576-8401, FTS 626-8401

Available to the public from the

National Technical Information Service

U.S. Department of Commerce

5285 Port Royal Rd.,

Springfield, VA 22161 
TDR-EBS-ST-000001 REV 00A

\author{
by \\ Joe Farmer \\ Dave Silberman \\ John Estill \\ Ken King \\ Steve Gordon \\ Larry Logotetta
}

August 1999

Lawrence Livermore National Laboratory

Livermore, California 



\section{CONTENTS}

Page

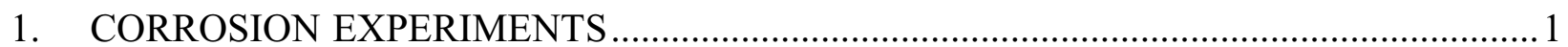

2. ANALYSES OF CHROMIUM IN SOLUTIONS FROM CORROSION

EXPERIMENTS 1

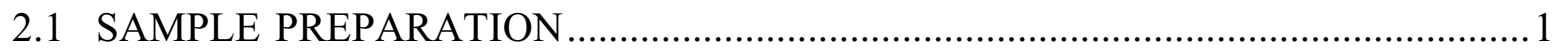

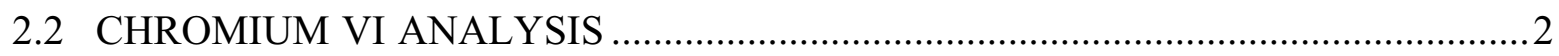

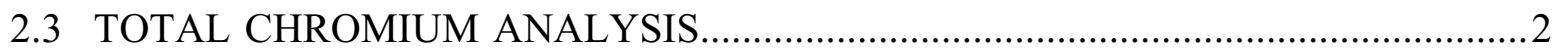

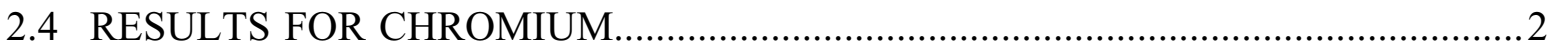

3. ANALYSES OF IRON IN SOLUTIONS FROM CORROSION EXPERIMENTS..............

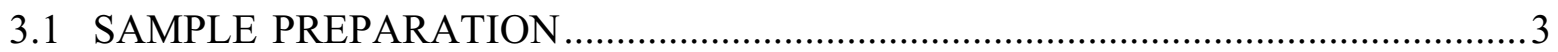

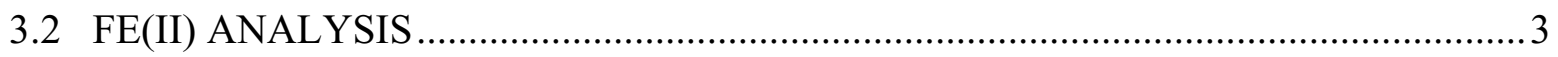

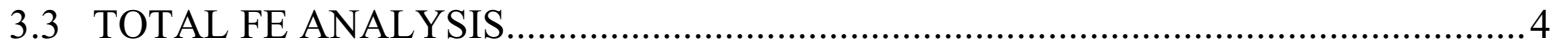

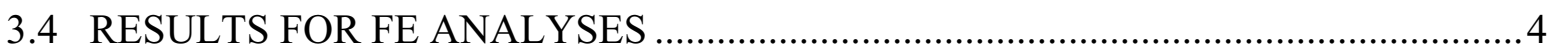

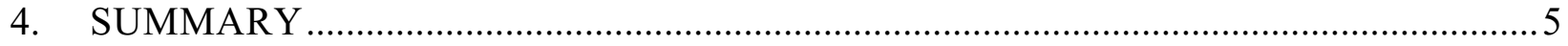

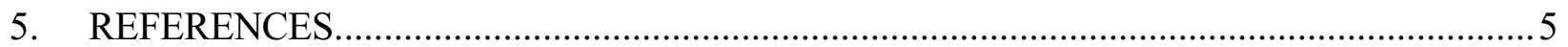




\section{TABLES}

Page

Table 1. Summary of Conditions for Experiments with Artificial Crevices (at $20^{\circ} \mathrm{C}$ )........... 6

Table 2. Chromium Analyses from Experiments with Artificial Crevices (at $20^{\circ} \mathrm{C}$ )............. 7

Table 3. Iron Analyses from Experiments with Artificial Crevices (at $\left.20^{\circ} \mathrm{C}\right) \ldots \ldots \ldots \ldots \ldots \ldots . \ldots$

Table 4. Summary of Conditions for Cyclic Polarization Measurements....................... 9

Table 5. Chromium Analyses for Cyclic Polarization Measurements .........................10

Table 6. Iron Analyses for Cyclic Polarization Measurements.............................11 


\section{CORROSION EXPERIMENTS}

Thus far, electrolytes with dissolved and precipitated metal have been collected from two generic types of corrosion experiments: crevice corrosion experiments described in detail in Activity Plan E-20-81 Rev. 2 found in scientific notebook (SN) \#00419 (consistent with Activity Plan E-20-89 found in SN \#00420); and cyclic polarization experiments described in detail in Activity Plan E20-43/44 found in SN \#00424 and SN \#00436. Crevice experiments are summarized in Table 1, and cyclic polarization measurements are summarized in Table 4 . These electrolytes have been analyzed to determine the quantities of dissolved and precipitated metal and the oxidation states of dissolved species.

\section{ANALYSES OF CHROMIUM IN SOLUTIONS FROM CORROSION EXPERIMENTS}

\subsection{SAMPLE PREPARATION}

The oxidation state of chromium in each of 28 electrolyte samples from corrosion experiments was determined. The plan was to determine the total $\mathrm{Cr}$ and $\mathrm{Cr}(\mathrm{VI})$ concentrations, thereby making it possible to estimate the $\mathrm{Cr}(\mathrm{III})$ concentration by difference. In this study, samples were stored prior to analysis for approximately one week without refrigeration.

Thirteen samples contained either a brown-orange or a white precipitate. The brown-orange precipitate was thought to be precipitated iron and chromium. Each sample bottle was weighed and then shaken vigorously to uniformly suspend the precipitate. An aliquot was rapidly poured into and filtered through a $0.2-\mu \mathrm{m}$ polyethersulfone $50-\mu \mathrm{m}$ membrane filtration unit (Nalgene 165-0020). The sample bottle was reweighed to obtain the aliquot weight taken. The density of the filtrate was measured, and the volume of the aliquot taken for filtration was determined. The filtrate was transferred to $250-\mathrm{ml}$ polyethylene bottle. This was repeated for each of the 13 samples.

The remaining precipitate on the filter was washed three times $(3 \mathrm{X})$ with portions of distilled water to remove any residual solution, and the washings were discarded. The precipitate was extracted by allowing $5 \mathrm{ml}$ of $6 \mathrm{M}$ redistilled-grade $\mathrm{HCl}$ to sit on the sample and dissolve it. The precipitate was washed with $0.1 \mathrm{~N} \mathrm{H}_{2} \mathrm{SO}_{4}$ and collected into the tared receiving flask, which is the bottom portion of the filtration unit. The contents of the receiving flask were poured back onto the precipitate and allowed to extract it again. The precipitate was washed three times (3X) with small portions of distilled water, and the total volume of the extracted precipitate was stored in the receiving flask. The receiving flask was reweighed to obtain the extract weight captured. The density of the extract was measured, and the volume of the extract obtained was determined. This was repeated for each of the 13 samples. 


\subsection{CHROMIUM VI ANALYSIS}

The samples that had no precipitate were analyzed as received. The filtrates, extracts, and unfiltered solutions were analyzed for $\mathrm{Cr}(\mathrm{VI})$ using Environmental Protection Agency (EPA) method 7196A.

\subsection{TOTAL CHROMIUM ANALYSIS}

To obtain total chromium, any $\mathrm{Cr}$ (III) was first be oxidized to $\mathrm{Cr}(\mathrm{VI})$ and then analyzed by EPA method 7196A. Aliquots of the filtrates, extracts, and unfiltered solutions were oxidized using the procedure outlined in Method 3500-Cr B Colorimetric Method in the 20th Edition of Standard Methods for Water and Wastewater. Depending on chromium concentration, aliquots ranging from $0.1 \mathrm{ml}$ to $10 \mathrm{ml}$ were taken. As an aliquot was acidified, a drop of saturated potassium permanganate was added, and the sample was boiled. The excess potassium permanganate was reduced with 1 to $2 \mathrm{ml}$ of $0.5 \%$ (w/v) sodium azide solution. As before, the samples were then analyzed for $\mathrm{Cr}(\mathrm{VI})$. If the total $\mathrm{Cr}$ analysis was equal to the $\mathrm{Cr}(\mathrm{VI})$ analysis without the oxidation step, it was assumed that no $\mathrm{Cr}(\mathrm{III})$ was present.

The samples were analyzed using a Cary 2300 UV-VIS spectrophotometer at $540 \mathrm{~nm}$. The instrument was zeroed with distilled water in $1-\mathrm{cm}$ quartz cuvettes. A $1.0 \mu \mathrm{g} / \mathrm{ml} \mathrm{Cr}(\mathrm{VI})$ solution had an absorbance reading of 0.8 . The standard curve generated is linear to $2.0 \mu \mathrm{g} / \mathrm{ml} \mathrm{Cr}$ (VI). The data are reported as $\mu \mathrm{g} \mathrm{Cr} / \mathrm{ml}$ of original shaken aliquot.

\subsection{RESULTS FOR CHROMIUM}

Chromium analyses for the crevice experiments and cyclic polarization measurements are found in Table 2 and Table 5, respectively. Additional details have been published elsewhere (Farmer et al. 1999). In mild electrolytes and at low applied potential, little or no dissolved chromium could be detected (denoted ND). However, in some cases precipitates were formed. At near neutral pH and at applied potentials above the threshold potential for localized breakdown of the passive film, virtually all of the dissolved chromium appears to be in the hexavalent oxidation state $(\mathrm{Cr}(\mathrm{VI}))$. In acidic environments, such as crevice solutions formed during the crevice corrosion of $316 \mathrm{~L}$ and $\mathrm{C}-22$ samples in $4 \mathrm{M} \mathrm{NaCl}$, virtually all of the dissolved chromium appears to be in the trivalent oxidation state $(\mathrm{Cr}(\mathrm{III}))$. These general observations appear to be consistent with the Pourbaix diagram for chromium (Pourbaix 1974), pp. 256-271. At high $\mathrm{pH}$ and high anodic polarization ( $\mathrm{pH} \sim 8$ and $800 \mathrm{mV}$ vs. SHE), the predominate species is believed to be the soluble chromate anion $\left(\mathrm{CrO}_{4}{ }^{2-}\right)$. At the same $\mathrm{pH}$, but lower polarization ( $\mathrm{pH} \sim 8$ and $0 \mathrm{mV}$ vs. SHE), the predominate species are believed to be precipitates such as trivalent $\mathrm{Cr}(\mathrm{OH})_{3} \cdot \mathrm{n}\left(\mathrm{H}_{2} \mathrm{O}\right)$ and hexavalent $\mathrm{Cr}_{2} \mathrm{O}_{3}$. In acidified environments such as those found in crevices $(\mathrm{pH}<3)$, soluble $\mathrm{Cr}^{3+}$ is expected to form over a wide range of potential extending from $-400 \mathrm{mV}$ vs. SHE to 
approximately $1200 \mathrm{mV}$ vs. SHE. Again, this is consistent with the observations from the creviced samples. In earlier studies by the principal investigator, it has been found that low-level chromium contamination in groundwater is usually in the hexavalent oxidation state (Farmer et al. 1996).

\section{ANALYSES OF IRON IN SOLUTIONS FROM CORROSION EXPERIMENTS}

\subsection{SAMPLE PREPARATION}

An analytical request was made to determine the oxidation state of iron in each of 28 water samples. The plan was to determine both total $\mathrm{Fe}$ and $\mathrm{Fe}^{+2}$ giving $\mathrm{Fe}^{+3}$ by difference. Because the samples were already a week old before they reached the principal investigator, they were not refrigerated.

Thirteen samples contained either a brown-orange or a white precipitate. The brown-orange precipitate was thought to be precipitated iron and chromium. Each sample bottle was weighed and then shaken vigorously to uniformly suspend the precipitate. An aliquot was rapidly poured into and filtered through a $0.2-\mu \mathrm{m}$ polyethersulfone $50-\mu \mathrm{m}$ membrane filtration unit (Nalgene 165-0020). The sample bottle was reweighed to obtain the aliquot weight taken. The density of the filtrate was measured, and the volume of the aliquot taken for filtration was determined. The filtrate was transferred to a $250-\mathrm{ml}$ polyethylene bottle. This was repeated for each of the 13 samples.

The remaining precipitate on the filter was washed three times $(3 \mathrm{X})$ with portions of distilled water to remove any residual solution, and the washings were discarded. The precipitate was extracted by allowing $5 \mathrm{ml}$ of $6 \mathrm{M}$ redistilled-grade $\mathrm{HCl}$ to sit on the sample and dissolve it. The precipitate was washed with $0.1 \mathrm{~N} \mathrm{H}_{2} \mathrm{SO}_{4}$ and collected into the tared receiving flask, which is the bottom portion of the filtration unit. The contents of the receiving flask were poured back onto the precipitate and allowed to extract it again. The precipitate was washed three times (3X) with small portions of distilled water, and the total volume of the extracted precipitate was stored in the receiving flask. The receiving flask was reweighed to obtain the extract weight captured. The density of the extract was measured, and the volume of the extract obtained was determined. This was repeated for each of the 13 samples.

\subsection{FE(II) ANALYSIS}

The samples that had no precipitate were analyzed as received. The filtrates, extracts, and unfiltered solutions were analyzed for $\mathrm{Fe}^{+2}$ and total $\mathrm{Fe}$ using method 3500-Fe B Phenanthroline Method (pages 76-78) in the 20th Edition of Standard Methods for the Examination of Water and Wastewater. 


\subsection{TOTAL FE ANALYSIS}

depending on iron concentration, aliquots of the filtrates, extracts, and unfiltered solutions ranging from $0.1 \mathrm{ml}$ to $10 \mathrm{ml}$ were taken and acidified with $2 \mathrm{ml}$ of concentrated $\mathrm{HCl}$. To obtain total $\mathrm{Fe}$, $1 \mathrm{ml}$ of $10 \%$ hydroxylamine hydrochloride was added followed by $10 \mathrm{ml}$ of ammonium acetate buffer and $4 \mathrm{ml}$ of phenanthroline solution. The samples were diluted to exactly $100 \mathrm{ml}$ and analyzed for total $\mathrm{Fe}^{+2}$ as before. If the total $\mathrm{Fe}$ analysis with the reduction step was equal to the $\mathrm{Fe}^{+2}$ analysis without the reduction step, it was assumed that $\mathrm{Fe}^{+3}$ was not present.

The samples were analyzed using a Cary 2300 UV-VIS spectrophotometer at $510 \mathrm{~nm}$. The instrument was zeroed with distilled water in 1-cm quartz cuvettes. A $2.0 \mu \mathrm{g} / \mathrm{mL} \mathrm{Fe}^{+2}$ solution had an absorbance reading of 0.4 . The standard curve generated is linear to $10.0\left(\mathrm{~g} \mathrm{Fe}^{+2} / \mathrm{ml}\right.$. The data are reported as $\mu \mathrm{g} \mathrm{Fe} / \mathrm{ml}$ of original shaken aliquot.

The quantity of $\mathrm{Fe}^{+3}$ can be determined by calculating the difference between the total $\mathrm{Fe}$ and the $\mathrm{Fe}^{+2}$.

\subsection{RESULTS FOR FE ANALYSES}

Iron analyses for the iron measurements are found in Table 3 and 6, respectively. In most instances, virtually all of the iron was precipitated. In the case of crevice experiment $2 \mathrm{Q}(316 \mathrm{~L}$ in saturated $\mathrm{KCl}$ ), a high concentration of $\mathrm{Fe}(\mathrm{II})$ was detected in the actual crevice solution. Approximately $90 \%$ of the crevice solution was in the +2 oxidation state, with the remaining $10 \%$ in the +3 oxidation state. In this case, all $\mathrm{Fe}$ found outside of the crevice mouth was in the form of a precipitate. In the case of crevice experiment $25 \mathrm{Q}$ (C-22 in SCW with the addition of 4 moles per liter of $\mathrm{NaCl}$ ) and crevice experiment $26 \mathrm{Q}(\mathrm{C}-22$ in SCW), the dissolved $\mathrm{Fe}$ was in a relatively high oxidation state $(\mathrm{Fe}(\mathrm{III}))$. In this case, the measured $\mathrm{pH}$ values at the end of the experiment were 7.08 and 8.50, respectively (Table 1). In general, dissolved Fe measured during the crevice experiments appeared to be Fe(II) in acidic media and Fe(III) in near-neutral and alkaline solutions (Table 3).

In the case of cyclic polarization measurements, the dissolved Fe measured at the end of some cyclic polarization measurements with $\mathrm{C}-22$ appeared to be in the $\mathrm{Fe}(\mathrm{III})$ state. This is probably due to the high electrochemical potential at which these species were generated during the potential scan. Note that the reversal potential was approximately $1200 \mathrm{mV}$ vs. $\mathrm{Ag} / \mathrm{AgCl}$ during these scans (Table 6).

These results are also consistent with the corresponding Pourbaix diagrams. For example, in acidic media ( $\mathrm{pH} 0$ to 1 ), $\mathrm{Fe}^{+2}$ would be expected to form at relatively low potential, with conversion to $\mathrm{Fe}^{+3}$ at high applied potential (greater than about $700 \mathrm{mV}$ vs. SHE). In neutral to alkaline $\mathrm{pH}$, precipitates of $\mathrm{Fe}(\mathrm{OH})_{2}, \mathrm{Fe}(\mathrm{OH})_{3}, \mathrm{Fe}_{2} \mathrm{O}_{3}$, or $\mathrm{Fe}_{3} \mathrm{O}_{4}$ would be expected, with some hydrolyzed species of $\mathrm{Fe}^{+3}$ possible. 


\section{SUMMARY}

At near neutral $\mathrm{pH}$ and at applied potentials above the threshold potential for localized breakdown of the passive film, virtually all of the dissolved chromium appeared to be in the hexavalent oxidation state $(\mathrm{Cr}(\mathrm{VI}))$. In acidic environments, such as crevice solutions formed during the crevice corrosion of 316L and C-22 samples in $4 \mathrm{M} \mathrm{NaCl}$, virtually all of the dissolved chromium appeared to be in the trivalent oxidation state $(\mathrm{Cr}(\mathrm{III}))$. These general observations appear to be consistent with the Pourbaix diagram for chromium (Pourbaix 1974), pp. 307-321. At high $\mathrm{pH}$ and high anodic polarization $(\mathrm{pH} \sim 8$ and $800 \mathrm{mV}$ vs. SHE), the predominate species is believed to be the soluble chromate anion $\left(\mathrm{CrO}_{4}{ }^{2-}\right)$. At the same $\mathrm{pH}$, but lower polarization ( $\mathrm{pH} \sim 8$ and $0 \mathrm{mV}$ vs. SHE), the predominate species are believed to be precipitates such as trivalent $\mathrm{Cr}(\mathrm{OH})_{3} \cdot \mathrm{n}\left(\mathrm{H}_{2} \mathrm{O}\right)$ and hexavalent $\mathrm{Cr}_{2} \mathrm{O}_{3}$. In acidified environments such as those found in crevices $(\mathrm{pH}<3)$, soluble $\mathrm{Cr}^{3+}$ is expected to form over a wide range of potential extending from $400 \mathrm{mV}$ vs. SHE to approximately $1200 \mathrm{mV}$ vs. SHE. Again, this is consistent with the observations from the creviced samples. In earlier studies by the principal investigator, it has been found that low-level chromium contamination in ground water is usually in the hexavalent oxidation state (Farmer et al. 1996).

In general, dissolved iron measured during the crevice experiments appears to be Fe(II) in acidic media and Fe(III) in near-neutral and alkaline solutions (Table 3). In the case of cyclic polarization measurements, the dissolved iron measured at the end of some cyclic polarization measurements with C-22 appeared to be in the Fe(III) state. This is probably due to the high electrochemical potential at which these species were generated during the potential scan. Note that the reversal potential was approximately $1200 \mathrm{mV}$ vs. $\mathrm{Ag} / \mathrm{AgCl}$ during these scans (Table 6). These results are also consistent with the corresponding Pourbaix diagrams. For example, in acidic media ( $\mathrm{pH} 0$ to 1 ), $\mathrm{Fe}^{+2}$ would be expected to form at relatively low potential, with conversion to $\mathrm{Fe}^{+3}$ at high applied potential (greater than about $700 \mathrm{mV}$ vs. SHE). In neutral to alkaline $\mathrm{pH}$, precipitates of $\mathrm{Fe}(\mathrm{OH})_{2}, \mathrm{Fe}(\mathrm{OH})_{3}, \mathrm{Fe}_{2} \mathrm{O}_{3}$, or $\mathrm{Fe}_{3} \mathrm{O}_{4}$ would be expected, with some hydrolyzed species of $\mathrm{Fe}^{+3}$ possible.

\section{REFERENCES}

Farmer, J.C., Bahowick, S.M., Harrar, J.E., Fix, D.V., Martinelli, R.E., Vu, A.K., and Carroll, K.L. 1996. "Electrosorption of chromium ions on carbon aerogel electrodes as a means of remediating ground water." American Chemical Society Journal of Energy and Fuels 11(2): 337-347. (Also UCRL-JC-124565, Lawrence Livermore National Laboratory). ACC/TIC: TBD.

Farmer, J.C., Estill, J.C., and McCright, D.R. 1999. General and Localized Corrosion of Waste Package Outer Barrier. UCRL-ID-124993 DR. Livermore, California: Lawrence Livermore National Laboratory. ACC/TIC: TBD.

Pourbaix, M. 1974. Atlas of Electrochemical Equilibria in Aqueous Solutions. (2nd English edition) Houston, Texas: NACE International \& Cebelcor. ACC/TIC: TBD. 
Table 1. Summary of Conditions for Experiments with Artificial Crevices (at 20 C) [DTN LL990802205924.086]

\begin{tabular}{|c|c|c|c|c|c|c|c|c|c|c|c|}
\hline Expt. & ID \# & Alloy & Test Medium & $\begin{array}{c}\mathrm{E}_{\text {corr }}-\mathrm{High} \\
\mathrm{mV} \text { vs. } \\
\mathrm{Ag} / \mathrm{AgCl}\end{array}$ & $\begin{array}{c}\mathrm{E}_{\text {corr }} \text {-Low } \\
\mathrm{mV} \text { vs. } \\
\mathrm{Ag} / \mathrm{AgCl}\end{array}$ & $\begin{array}{c}E_{\text {applied }} \\
\mathrm{mV} \text { vs. } \\
\mathrm{Ag} / \mathrm{AgCl}\end{array}$ & $\begin{array}{c}\text { Duration } \\
- \text { hours }\end{array}$ & $\begin{array}{c}\text { Electrolyte } \\
\mathrm{pH}-\text { Start }\end{array}$ & $\begin{array}{l}\text { Electrolyte } \\
\text { pH-Finish }\end{array}$ & $\begin{array}{c}\text { Crevice } \\
\text { pH-Start }\end{array}$ & $\begin{array}{c}\text { Crevice } \\
\text { pH-Finish }\end{array}$ \\
\hline Crevice & $02 \mathrm{Q}$ & $316 \mathrm{LN}$ & $\begin{array}{l}\text { Satd. } \mathrm{KCl}- \\
\text { Reservoir }\end{array}$ & -237.60 & -242.41 & 800 & 37 & 7.09 & 6.18 & 7.22 & 1.24 \\
\hline Crevice & $02 \mathrm{Q}$ & $316 \mathrm{LN}$ & $\begin{array}{c}\text { Satd. } \mathrm{KCl}- \\
\text { Crevice Purge }\end{array}$ & -237.60 & -242.41 & 800 & 37 & 7.09 & 6.18 & 7.22 & 1.24 \\
\hline Crevice & $11 \mathrm{Q}$ & $316 \mathrm{~L}$ & $4 \mathrm{M} \mathrm{NaCl}$ & -117.21 & -133.34 & 800 & 3 & 8.02 & 10.18 & 7.95 & 0.97 \\
\hline Crevice & $12 \mathrm{Q}$ & $316 \mathrm{~L}$ & $4 \mathrm{M} \mathrm{NaCl}$ & -146.54 & -156.31 & 800 & 39 & 8.30 & 8.42 & 7.42 & 1.50 \\
\hline Crevice & $13 \mathrm{Q}$ & $316 \mathrm{~L}$ & $4 \mathrm{M} \mathrm{NaCl}$ & -127.65 & -189.82 & 400 & 20 & 6.43 & 8.89 & 7.96 & 1.24 \\
\hline Crevice & $14 \mathrm{Q}$ & $316 \mathrm{~L}$ & $4 \mathrm{M} \mathrm{NaCl}$ & -146.23 & -135.63 & 200 & 20 & 6.91 & 8.59 & 7.69 & 1.09 \\
\hline Crevice & $15 \mathrm{Q}$ & $316 \mathrm{~L}$ & $4 \mathrm{M} \mathrm{NaCl}+\mathrm{SCW}$ & & & & & & & & \\
\hline Crevice & $21 \mathrm{Q}$ & $\mathrm{C}-22$ & $4 \mathrm{M} \mathrm{NaCl}$ & -107.70 & -150.50 & 800 & 23 & 8.04 & 6.71 & 8.21 & 6.97 \\
\hline Crevice & $22 \mathrm{Q}$ & C-22 & $4 \mathrm{M} \mathrm{NaCl}$-Reservoir & -97.50 & -163.20 & 400 & 66 & 8.14 & 6.98 & 8.50 & 4.69 \\
\hline Crevice & $22 \mathrm{Q}$ & $\mathrm{C}-22$ & $4 \mathrm{M} \mathrm{NaCl}-\mathrm{Cell}$ & -97.50 & -163.20 & 400 & 66 & 8.14 & 6.98 & 8.50 & 4.69 \\
\hline Crevice & $23 \mathrm{Q}$ & $\mathrm{C}-22$ & $4 \mathrm{M} \mathrm{NaCl}$ & -89.60 & -118.50 & 1100 & 26 & 6.98 & 8.99 & 4.69 & 0.38 \\
\hline Crevice & $24 \mathrm{Q}$ & $\mathrm{C}-22$ & $4 \mathrm{M} \mathrm{NaCl}+\mathrm{SCW}$ & -132.50 & -143.20 & 1100 & 5 & 8.04 & 8.04 & 8.04 & 6.77 \\
\hline Crevice & $25 \mathrm{Q}$ & $\mathrm{C}-22$ & $4 \mathrm{M} \mathrm{NaCl}+\mathrm{SCW}$ & -75.53 & -1.96 & 1100 & 5 & 8.25 & 8.24 & 8.21 & 7.08 \\
\hline Crevice & $26 \mathrm{Q}$ & $\mathrm{C}-22$ & SCW & -120.50 & -133.30 & 0 to 800 & 70 & 8.25 & 8.55 & 8.23 & 8.50 \\
\hline Crevice & $27 \mathrm{Q}$ & $\mathrm{C}-22$ & $4 \mathrm{M} \mathrm{NaCl}$ & -64.70 & -97.80 & 800 & 116 & 8.26 & 8.44 & 7.24 & -0.05 \\
\hline
\end{tabular}


Table 2. Chromium Analyses from Experiments with Artificial Crevices (at $20^{\circ} \mathrm{C}$ ) [DTN LL990802205924.086]

\begin{tabular}{|c|c|c|c|c|c|c|c|c|c|}
\hline Expt. & ID \# & Alloy & Test Medium & $\begin{array}{c}\text { Total } \\
\text { Dissolved } \mathrm{Cr} \\
(\mu \mathrm{g} / \mathrm{ml})\end{array}$ & $\begin{array}{c}\text { Dissolved } \\
\text { Cr(VI) } \\
(\mu \mathrm{g} / \mathrm{ml})\end{array}$ & $\begin{array}{c}\text { Dissolved } \\
\text { Cr(III) } \\
(\mu \mathrm{g} / \mathrm{ml})\end{array}$ & $\begin{array}{l}\text { Dissolved Cr } \\
\text { MDL }(\mu \mathrm{g} / \mathrm{ml})\end{array}$ & $\begin{array}{c}\text { Cr } \\
\text { Precipitate } \\
(\mu \mathrm{g} / \mathrm{ml})\end{array}$ & $\begin{array}{c}\text { Precipitated Cr } \\
\text { MDL } \\
(\mu \mathrm{g} / \mathrm{ml})\end{array}$ \\
\hline Crevice & $02 \mathrm{Q}$ & $316 \mathrm{LN}$ & $\begin{array}{l}\text { Satd. } \mathrm{KCl}- \\
\text { Reservoir }\end{array}$ & ND & ND & ND & 0.1 & 7.5 & 0.1 \\
\hline Crevice & $02 \mathrm{Q}$ & 316LN & Satd. $\mathrm{KCl}-$ Crevice & 170 & ND & 170 & 10 & no analysis & no analysis \\
\hline Crevice & $11 \mathrm{Q}$ & $316 \mathrm{~L}$ & $4 \mathrm{M} \mathrm{NaCl}$ & ND & ND & ND & 0.1 & ND & 0.1 \\
\hline Crevice & $12 \mathrm{Q}$ & $316 \mathrm{~L}$ & $4 \mathrm{M} \mathrm{NaCl}$ & ND & ND & ND & 0.1 & 12.0 & 0.1 \\
\hline Crevice & $13 Q$ & $316 \mathrm{~L}$ & $4 \mathrm{M} \mathrm{NaCl}$ & ND & ND & ND & 0.1 & 3.6 & 0.1 \\
\hline Crevice & $14 \mathrm{Q}$ & $316 \mathrm{~L}$ & $4 \mathrm{M} \mathrm{NaCl}$ & ND & ND & ND & 0.1 & 20.0 & 0.1 \\
\hline Crevice & $15 Q$ & $316 \mathrm{~L}$ & $4 \mathrm{M} \mathrm{NaCl}+\mathrm{SCW}$ & ND & ND & ND & 0.1 & ND & 0.1 \\
\hline Crevice & $21 \mathrm{Q}$ & $\mathrm{C}-22$ & $4 \mathrm{M} \mathrm{NaCl}$ & ND & ND & ND & 0.1 & ND & 0.1 \\
\hline Crevice & $22 \mathrm{Q}$ & $\mathrm{C}-22$ & $4 \mathrm{M} \mathrm{NaCl}-$ Reservoir & ND & ND & ND & 0.1 & 2.0 & 0.1 \\
\hline Crevice & $22 \mathrm{Q}$ & C-22 & $4 \mathrm{M} \mathrm{NaCl}-$ Cell & ND & ND & ND & 0.1 & 3.3 & 0.1 \\
\hline Crevice & $23 \mathrm{Q}$ & $\mathrm{C}-22$ & $4 \mathrm{M} \mathrm{NaCl}$ & 0.9 & 0.8 & 0.1 & 0.1 & 6.6 & 0.1 \\
\hline Crevice & $24 Q$ & $\mathrm{C}-22$ & $4 \mathrm{M} \mathrm{NaCl}+\mathrm{SCW}$ & no analysis & no analysis & no analysis & no analysis & no analysis & no analysis \\
\hline Crevice & $25 \mathrm{Q}$ & $\mathrm{C}-22$ & $4 \mathrm{M} \mathrm{NaCl}+\mathrm{SCW}$ & 0.8 & 0.8 & ND & 0.1 & ND & 0.1 \\
\hline Crevice & $26 \mathrm{Q}$ & $\mathrm{C}-22$ & SCW & 2.5 & 2.3 & 0.2 & 0.1 & 2.1 & 0.1 \\
\hline Crevice & $27 \mathrm{Q}$ & $\mathrm{C}-22$ & $4 \mathrm{M} \mathrm{NaCl}$ & no analysis & no analysis & no analysis & no analysis & no analysis & no analysis \\
\hline
\end{tabular}


Table 3. Iron Analyses from Experiments with Artificial Crevices (at $20^{\circ} \mathrm{C}$ ) [DTN LL990802205924.086]

\begin{tabular}{|c|c|c|c|c|c|c|c|c|c|}
\hline Expt. & ID \# & Alloy & Test Medium & $\begin{array}{c}\text { Total } \\
\text { Dissolved Fe } \\
(\mu \mathrm{g} / \mathrm{ml})\end{array}$ & $\begin{array}{c}\text { Dissolved } \\
\text { Fe(III) } \\
(\mu \mathrm{g} / \mathrm{ml}) \\
\end{array}$ & $\begin{array}{c}\text { Dissolved } \\
\text { Fe(II) } \\
(\mu \mathrm{g} / \mathrm{ml}) \\
\end{array}$ & $\begin{array}{l}\text { Dissolved Fe } \\
\text { MDL }(\mu \mathrm{g} / \mathrm{ml})\end{array}$ & $\begin{array}{c}\text { Fe } \\
\text { Precipitate } \\
(\mu \mathrm{g} / \mathrm{ml}) \\
\end{array}$ & $\begin{array}{c}\text { Precipitated } \\
\text { Fe MDL } \\
(\mu \mathrm{g} / \mathrm{ml})\end{array}$ \\
\hline Crevice & $02 \mathrm{Q}$ & 316LN & Satd. KCl-Reservoir & ND & ND & ND & 0.3 & 32 & 4 \\
\hline Crevice & $02 \mathrm{Q}$ & 316LN & Satd. $\mathrm{KCl}-$ Crevice & 709 & 66 & 643 & 30 & no analysis & no analysis \\
\hline Crevice & $11 \mathrm{Q}$ & $316 \mathrm{~L}$ & $4 \mathrm{M} \mathrm{NaCl}$ & ND & ND & ND & 0.3 & ND & 3 \\
\hline Crevice & $12 \mathrm{Q}$ & $316 \mathrm{~L}$ & $4 \mathrm{M} \mathrm{NaCl}$ & ND & ND & ND & 0.3 & 48 & 4 \\
\hline Crevice & $14 \mathrm{Q}$ & $316 \mathrm{~L}$ & $4 \mathrm{M} \mathrm{NaCl}$ & ND & ND & ND & 0.3 & $131-148$ & 4 \\
\hline Crevice & $15 Q$ & $316 \mathrm{~L}$ & $4 \mathrm{M} \mathrm{NaCl}+\mathrm{SCW}$ & ND & ND & ND & 0.3 & ND & 3 \\
\hline Crevice & $21 Q$ & $\mathrm{C}-22$ & $4 \mathrm{M} \mathrm{NaCl}$ & ND & ND & ND & 0.3 & 8 & 3 \\
\hline Crevice & $22 \mathrm{Q}$ & $\mathrm{C}-22$ & $4 \mathrm{M} \mathrm{NaCl}-$ Reservoir & ND & ND & ND & 0.3 & 7 & 4 \\
\hline Crevice & $22 \mathrm{Q}$ & $\mathrm{C}-22$ & $4 \mathrm{M} \mathrm{NaCl}-$ Cell & ND & ND & ND & 0.3 & 13 & 4 \\
\hline Crevice & $23 \mathrm{Q}$ & $\mathrm{C}-22$ & $4 \mathrm{M} \mathrm{NaCl}$ & 0.8 & 0.8 & ND & 0.3 & 14 & 4 \\
\hline Crevice & $25 \mathrm{Q}$ & $\mathrm{C}-22$ & $4 \mathrm{M} \mathrm{NaCl}+\mathrm{SCW}$ & 0.8 & 0.8 & ND & 0.3 & ND & 3 \\
\hline Crevice & $26 \mathrm{Q}$ & $\mathrm{C}-22$ & SCW & 1.4 & 1.4 & ND & 0.3 & ND & 3 \\
\hline Crevice & $27 \mathrm{Q}$ & $\mathrm{C}-22$ & $4 \mathrm{M} \mathrm{NaCl}$ & no analysis & no analysis & no analysis & no analysis & no analysis & no analysis \\
\hline
\end{tabular}


Table 4. Summary of Conditions for Cyclic Polarization Measurements [DTN LL990802205924.086]

\begin{tabular}{|c|c|c|c|c|c|c|c|c|c|}
\hline Expt. & ID \# & Alloy & Test Medium & $\begin{array}{c}\text { Temp. } \\
\left({ }^{\circ} \mathrm{C}\right)\end{array}$ & $\begin{array}{c}E_{\text {corr }}-\text { High } \\
\mathrm{mV} \text { vs. } \\
\mathrm{Ag} / \mathrm{AgCl}\end{array}$ & $\begin{array}{c}\text { E }_{\text {reversal }} \\
\mathrm{mV} \text { vs. } \\
\mathrm{Ag} / \mathrm{AgCl}\end{array}$ & $\begin{array}{c}\text { Scan Rate } \\
\mathrm{mV} / \mathrm{sec}\end{array}$ & $\begin{array}{l}\text { Electrolyte } \\
\text { pH—Start }\end{array}$ & $\begin{array}{l}\text { Electrolyte } \\
\text { pH-Finish }\end{array}$ \\
\hline $\mathrm{CP}$ & DEA 025031899 & C-22 & SDW & 30 & -55 & 1200 & 0.17 & 8.61 & 8.74 \\
\hline $\mathrm{CP}$ & DEA 026031999 & $\mathrm{C}-22$ & SDW & 60 & -137 & 1200 & 0.17 & 8.46 & 9.52 \\
\hline $\mathrm{CP}$ & DEA 027032099 & $\mathrm{C}-22$ & SDW & 90 & -191 & 1200 & 0.17 & 8.61 & 10.12 \\
\hline $\mathrm{CP}$ & DEA 024031899 & $\mathrm{C}-22$ & SDW & 90 & -162 & 1190 & 0.17 & 8.38 & 9.61 \\
\hline $\mathrm{CP}$ & DEA 028032299 & C-22 & SAW & & & & 0.17 & 2.77 & 2.95 \\
\hline $\mathrm{CP}$ & DEA 029032299 & C-22 & SAW & 90 & -171 & 1200 & 0.17 & 2.77 & 2.94 \\
\hline $\mathrm{CP}$ & DEA 031032499 & $\mathrm{C}-22$ & SAW & 90 & -150 & 1200 & 0.17 & 2.79 & 2.87 \\
\hline $\mathrm{CP}$ & PEA 001032399 & $316 \mathrm{~L}$ & ScW & 60 & -185 & 1200 & 0.17 & 8.14 & 9.46 \\
\hline $\mathrm{CP}$ & PEA 002032499 & $316 \mathrm{~L}$ & ScW & 90 & -263 & 1200 & 0.17 & 8.14 & 9.46 \\
\hline Blank & None & None & $4 \mathrm{M} \mathrm{NaCl}$ & 20 & None & None & None & & \\
\hline Blank & None & None & SDW & 20 & None & None & None & & \\
\hline Blank & None & None & SCW & 20 & None & None & None & & \\
\hline Blank & None & None & SAW & 20 & None & None & None & & \\
\hline
\end{tabular}


Table 5. Chromium Analyses for Cyclic Polarization Measurements [DTN LL990802205924.086]

\begin{tabular}{|l|c|c|c|c|c|c|c|c|}
\hline Expt. & ID \# & Alloy & Test Medium & Temp. $\left({ }^{\circ} \mathbf{C}\right)$ & $\begin{array}{c}\text { Total Unfiltered } \\
\mathbf{C r}(\mu \mathbf{g} / \mathbf{m l})\end{array}$ & $\begin{array}{c}\text { Unfiltered } \\
\mathbf{C r}(\mathbf{V I})(\mu \mathbf{g} / \mathbf{m l})\end{array}$ & $\begin{array}{c}\text { Unfiltered } \\
\mathbf{C r}(\mathbf{I I})(\mu \mathbf{g} / \mathbf{m l})\end{array}$ & $\begin{array}{c}\text { Unfiltered Cr MDL } \\
(\mu \mathbf{g} / \mathbf{m l})\end{array}$ \\
\hline CP & DEA 025 031899 & C-22 & SDW & 30 & ND & 0.1 & no estimate & 0.1 \\
\hline CP & DEA 026 031999 & C-22 & SDW & 60 & 0.3 & 0.3 & 0 & 0.1 \\
\hline CP & DEA 027 032099 & C-22 & SDW & 90 & 0.2 & 0.3 & no estimate & 0.1 \\
\hline CP & DEA 024 031899 & C-22 & SDW & 90 & 0.2 & 0.2 & 0 & 0.1 \\
\hline CP & DEA 028 032299 & C-22 & SAW & & 7.9 & 6.1 & 1.8 & 0.2 \\
\hline CP & DEA 029 032299 & C-22 & SAW & 90 & 11.0 & 8.9 & 2.1 & 0.2 \\
\hline CP & DEA 031 032499 & C-22 & SAW & 90 & 8.4 & 5.8 & 2.6 & 0.2 \\
\hline CP & PEA 001 032399 & $316 L$ & SCW & 60 & ND & ND & ND & 0.1 \\
\hline CP & PEA 002 032499 & $316 L$ & SCW & 90 & ND & ND & ND & 0.1 \\
\hline Blank & None & None & 4 M NaCl & 20 & ND & ND & ND & 0.1 \\
\hline Blank & None & None & SDW & 20 & ND & ND & ND & 0.1 \\
\hline Blank & None & None & SCW & 20 & ND & ND & ND & 0.1 \\
\hline Blank & None & None & SAW & 20 & ND & ND & ND & 0.1 \\
\hline
\end{tabular}


Table 6. Iron Analyses for Cyclic Polarization Measurements [DTN LL990802205924.086]

\begin{tabular}{|l|c|c|c|c|c|c|c|c|}
\hline Expt. & ID \# & Alloy & Test Medium & Temp. $\left({ }^{\circ} \mathbf{C}\right)$ & $\begin{array}{c}\text { Total } \\
\text { Unfiltered Fe } \\
(\mu \mathbf{g} / \mathbf{m l})\end{array}$ & $\begin{array}{c}\text { Unfiltered } \\
\text { Fe(III) }(\mu \mathbf{g} / \mathbf{m l})\end{array}$ & $\begin{array}{c}\text { Unfiltered } \\
\mathbf{F e}(\mathbf{I I})(\mu \mathbf{g} / \mathbf{m I})\end{array}$ & $\begin{array}{c}\text { Unfiltered Fe } \\
\mathbf{M D L}(\mu \mathbf{g} / \mathbf{m I})\end{array}$ \\
\hline CP & DEA 025 031899 & C-22 & SDW & 30 & & & \\
\hline CP & DEA 026 031999 & C-22 & SDW & 60 & ND & ND & 0.3 & \\
\hline CP & DEA 027 032099 & C-22 & SDW & 90 & ND & ND & 0.3 & \\
\hline CP & DEA 024 031899 & C-22 & SDW & 90 & ND & ND & 0.3 & \\
\hline CP & DEA 028 032299 & C-22 & SAW & & 0.8 & 0.5 & 0.3 & 0.3 \\
\hline CP & DEA 029 032299 & C-22 & SAW & 90 & 0.6 & 0.6 & ND & 0.3 \\
\hline CP & DEA 031 032499 & C-22 & SAW & 90 & 1.2 & 0.8 & 0.4 & 0.3 \\
\hline CP & PEA 001 032399 & 316L & SCW & 60 & 0.3 & 0.3 & ND & 0.3 \\
\hline CP & PEA 002 032499 & 316L & SCW & 90 & ND & ND & ND & 0.3 \\
\hline Blank & None & None & 4 M NaCl & 20 & ND & ND & ND & 0.3 \\
\hline Blank & None & None & SDW & 20 & ND & ND & ND & 0.3 \\
\hline Blank & None & None & SCW & 20 & ND & ND & ND & 0.3 \\
\hline Blank & None & None & SAW & 20 & ND & ND & ND & 0.3 \\
\hline
\end{tabular}

